KS. MARIAN RADWAN SCJ* - LUBLIN

IRENA WODZIANOWSKA** - LUBLIN

\title{
METODY FINANSOWANIA KOŚCIOLA KATOLICKIEGO W ROSJI W XIX WIEKU. PRZYCZYNEK ARCHIWALNY
}

\section{Przesłanki polityczne}

Chcąc mówić o losach Kościoła katolickiego w Rosji XIX wieku należy przede wszystkim uwzględnić naczelne założenia ideologiczne motywujące funkcjonowanie instytucji religijnych $\mathrm{w}$ tym kraju. Ideologie te sprowadzają się głównie do cezaropapizmu i pierwszych haseł słowianofilstwa. Ojcem pierwszego nurtu był czołowy władca kraju na początku XVIII wieku - Piotr I - który za wzorem protestanckim, hołdował zasadzie cuius regio eius religio. Dokonał on zmian w organizacji Cerkwi prawosławnej zastępując urząd patriarchy Synodem, i de facto stając sam na jego czele. Cezaropapizm XIX-wiecznej Rosji przybierający przeróżne formy, w odniesieniu do Kościoła katolickiego, ucieleśniał się przede wszystkim w jego stopniowym uniezależnianiu od Stolicy Apostolskiej, tworzeniu norm prawnych izolujących katolików od Rzymu oraz lokalnych instytucji blokujących związki z Kurią Rzymską. Tak doszło do powołania do życia 13 (25) listopada 1801 r. przez cara Aleksandra I Kolegium Rzymsko-katolickiego, zlokalizowanego w stolicy kraju - Sankt-Petersburgu. Krokiem ośmielającym cara na takie posunięcie były inicjatywy jego babci - Katarzyny II, która jeszcze w 1766 roku podporządkowała gminę katolicką w mieście nad Newą istniejącemu tu Justickolegium inflancko-estońsko-finlandzkiemu (1766 r.). Justickolegium miały podlegać wówczas wszystkie sprawy administracyjne i dyscyplinarne dotyczące zarówno wiernych jak i duchowieństwa katolickiego ${ }^{1}$. Trzy lata później (w 1769 r.) caryca ogłosiła reglament określający status katolików w Rosji,

* ks. Marian Radwan SCJ - prof. historii, emerytowany pracownik Instytutu Historii KUL, e-mail:mradwan@scj.pl

** Irena Wodzianowska - dr historii, adiunkt w Katedrze Historii i Historiografii Europy Wschodniej KUL, e-mail: irkawod@kul.lublin.pl

${ }^{1}$ Полное собрание законов Российской империи (dalej: ПС3), ч. I, т. 26, nr 20053; por. A. Petrani, Kolegium Duchowne w Petersburgu, Lublin 1950, s. 32. 
a następnie bezprawnie powołała wileńskiego sufragana Stanisława Bohusz-Siestrzeńcewicza najpierw na biskupa białoruskiego (1773 r.), a następnie na administratora niekanonicznego arcybiskupstwa mohylewskiego (1782 r.), nim rok później nastąpiło kanoniczne erygowanie takiej diecezji w Mohylewie nad Dnieprem. Kiedy po ostatnim rozbiorze Rzeczypospolitej ${ }^{2}$ w granicach rozszerzonej na zachód Rosji znacznie przybyło ludności katolickiej, kolejny władca rosyjski Paweł I, przy Justickolegium utworzył specjalny departament dla tej kategorii nowych obywateli. Katolicy swe sprawy mogli więc rozpatrywać najpierw w konsystorzach diecezjalnych, w drugiej instancji kierować się właśnie do nowo utworzonego departamentu, a Senat miał być trzecią instytucją odwoławczą. W spomniany departament wnet został usamodzielniony, a na jego prezesa władze carskie powołały metropolitę S. Siestrzeńcewicza.

Z woli Katarzyny II w Petersburgu i w innych ośrodkach kraju pracowali ocaleni od kasaty jezuici, a ich przełożonym generalnym był pochodzący z Austrii o. Gabriel Gruber (1740-1805). Pozostając w dobrych stosunkach z carem Pawłem I w 1800 r. doprowadził on do modyfikacji wspomnianego reglamentu z 1769 roku, dzięki czemu zakony zostały wyjęte spod jurysdykcji biskupa, na co trudno było przystać Siestrzeńcewiczowi. W tych okolicznościach i z powodu podobnych problemów metropolita został zmuszony do opuszczenia stolicy, jednak po śmierci cara (1801 r.) powrócił na swe stanowisko, a nowy władca na tronie, wraz z dobraną ekipą przygotował nowe sposoby kierowania Kościołem katolickim w swym kraju i dalszego uniezależnienia go od papieża. W tym kierunku prowadziły wielorakie działania centralnych władz rosyjskich, jak również powołanie do istnienia wspomnianego Kolegium katolickiego ${ }^{3}$. Jego definicja była raczej niejasna - określone jako Konsystorz Naczelny (czyli podlegać mu miały wszystkie konsystorze diecezjalne), a czasem używano nazwy - Główny Zarząd Duchowny. Precyzyjnie natomiast ustalono skład osobowy tej nowej instytucji i jej zadania. Na czele miał stać każdorazowy arcybiskup mohylewski oraz jeden biskup i jeden prałat, mianowani przez cara. W skład Kolegium wchodziło ponadto sześciu asesorów, duchownych, wybranych w sześciu diecezjach - mohylewskiej, wileńskiej, telszewskiej, mińskiej, łucko-żytomierskiej, kamienieckiej oraz świecki personel (prokurator, dwu sekretarzy, tłumacz). Mimo że gremium podstawowe stanowili tu duchowni, to była to instytucja państwowa, utworzona na życzenie władcy i bez zgody Stolicy Apostolskiej. Na utrzymanie tego niekanonicznego zespołu przewidziano 18500 rubli rocznie ${ }^{4}$.

Pozornie Kolegium podlegało metropolicie mohylewskiemu, a faktycznie kierował nim prokurator, $\mathrm{z}$ reguły oddelegowany do tej funkcji były pracownik MSW, prawosławny lub protestant. Wszystkie dokumenty wychodzące z tej kancelarii musiały posiadać jego aprobatę ${ }^{5}$.

${ }^{2}$ Rosja przyłączyła do swego imperium ponad $60 \%$ ziem Rzeczypospolitej. Por. A. Nowak, Geneza Powstania: polityka rosyjska wobec Polski 1815-1863: www.youtube.com/watch?v=qIO9xCzs4ny (dostęp: 12. 07. 2014 r.).

${ }^{3}$ Petrani, Kolegium Duchowne, s. 33.

${ }^{4}$ Tamże, s. 37. W 1853 r. koszty osobowe Kolegium wyniosły 15536 rubli, 43 kopiejki. Jednak w publikacji rozliczenia nie uwzględniono pensji thumacza i personelu pomocniczego. Список римско-католических духовных лии и учреждений, С.Петербург 1853, s. 3.

${ }^{5}$ ПСЗ, ч. I. т. 27, nr 22287; por. Российский Государственный Исторический Архив, Санкт -Петербург (dalej: РГИА), ф. 821, оп. 125, д. 41; A. Petrani, dz. cyt., s. 33-37. 
Kolegium nie tylko gromadziło wszystkie informacje o stanie organizacyjnym, personalnym i materialnym diecezji, parafii, klasztorów, ale uzurpowało sobie prawo rozstrzygania problemów kanonicznych i sądowych. Przyznano mu także kompetencje finansowe, pod pełnym nadzorem Ministerstwa Spraw Wewnętrznych i monarchy.

W pierwszej kolejności Kolegium zgromadziło dokładny opis uposażenia instytucji kościelnych - diecezji, parafii, klasztorów, utrzymujących się ze swych beneficjów. Zapewnienia ustawodawcy ogłoszone w statucie Kolegium dotyczące zakonów, ich administracji i niezależności od biskupów, bynajmniej nie gwarantowały im dobrej przyszłości. Środowisko dworskie Aleksandra I w pierwszej kolejności podważyło decyzje Katarzyny II, która mimo papieskiej kasaty jezuitów w 1773 r. zagwarantowała im dalsze istnienie i dobrą pozycję w swoim imperium. Nawet jej wnuk na tronie zgodził się by kolegium jezuickie w Połocku przemianować na Akademię Teologiczną, z przyznaniem jej przywilejów uniwersyteckich, kiedy nie powiodły się starania by temu zakonowi oddać wydział teologiczny uniwersytetu wileńskiego ${ }^{6}$. Mimo kilku pozytywnych gestów wobec synów duchownych św. Ignacego Loyoli Aleksander I w 1820 r. usunął ich ze swego kraju, przejmując wkrótce także pojezuickie domy, biblioteki, majątki i fundusze, nie tylko na terytoriach rosyjskich, ale także na ziemiach anektowanych po kolejnych rozbiorach Rzeczypospolitej. Na tych ostatnich skasowane dobra zakonu najpierw po 1773 r. przeszły w ręce Komisji Edukacji Narodowej, a po 1795 - po III rozbiorze - w ręce rosyjskiego ministerstwa skarbu. Fakty te w 1829 r. przypomniał senatowi A. S. Szyszkow stojący na czele Departamentu Spraw Duchownych Wyznań Obcych ${ }^{8}$. Z opublikowanego wówczas raportu wynika, że zmarły przed paru laty metropolita Siestrzeńcewicz (w 1826 r.), jako przewodniczący Kolegium Duchownego, w 1820 roku zgłosił, na ręce ówczesnego ministra spraw duchownych i oświecenia publicznego, projekt by utworzyć specjalny fundusz pomocowy na rzecz duchowieństwa katolickiego i biednych parafii. Najwidoczniej uposażenia parafii były bardzo zróżnicowane, czemu należało w jakiś sposób zaradzić9. Odsetki pochodzące z oprocentowania planowanej kwoty miały być wykorzystane do zapowiedzianych celów. Fundusz podstawowy został utworzony w 1820 roku za zgodą cara ze składek wpłacanych corocznie przez wszystkie diecezje metropolii mohylewskiej oraz z nadwyżek dochodów klasztorów oraz parafii ${ }^{10}$. Wileńska kapituła m.in. szczególnie majętna, została zobowiązana, by corocznie wpłacać na rzecz funduszu 3000 rubli. Fundusz powinien był wzrastać corocznie o 2575 rubli. Po kilku latach (1826 r.) tak zorganizowany kapitał pomocowy wynosił $18080 \mathrm{rb} .77 \mathrm{kop}$. w srebrze czyli $63232 \mathrm{rb} .72,5$ kop. asygnacjami, a w lutym 1828 roku już 34788 rb. 43 kop. srebrem czyli w asygnacjach

${ }^{6}$ ПСЗ, ч. II, т. 23, nr 24952.

${ }^{7}$ J. Poplatek, Komisja Edukacji Narodowej, Kraków 1973.

${ }^{8}$ РГИА, ф. 822, оп. 1, д. 400.

${ }^{9}$ ПСЗ, ч. II, т. 3, nr 2373.

${ }^{10}$ Archidiecezja mohylewska miała wpłacać corocznie 300 rubli, telszewska 600, łucko-żytomierska 450, kamieniecka 112 rb. 50 kop., mińska 112 rb. 50 kop. 
121763 rb. 62,5 kop. ${ }^{11} \mathrm{~W} 1829$ r. dołączono do niego ponadto 100000 rubli asygnacyjnych w zamian za majątki jezuickie zagarnięte przez rząd w $1820 \mathrm{roku}^{12}$.

Obok ideologii cezaropapizmu doniosłą rolę odgrywały pierwsze hasła słowianofilstwa. Wybitni luminarze rosyjscy ${ }^{13}$ byli przekonani, że wielką zasługą Katarzyny II była likwidacja Rzeczypospolitej, co jej następcom pozwalało na zbudowanie wszechsłowiańskiego imperium, jednowyznaniowego - czyli prawosławnego, i jednojęzycznego - czyli rosyjskiego. Ich projekty i poglądy przejmowali kolejni politycy i aparat administracyjny. Dawał im wyraz N. Murawiow już w 1830 r. Optując za budową prawosławnego państwa wszechsłowiańskiego główną przeszkodę widział w zakonach. Postulował, by władze zwróciły baczną uwagę na „fanatyczny” duch panujący w klasztorach i uniemożliwiający integrację ziem anektowanych przez Rosję z imperium ${ }^{14}$. W takim przekonaniu zredagował memoriał: О мерах принятых к ослаблению католицизма в Западном $K p a e^{15}$. Postulował on wówczas stopniową likwidację katolickich wspólnot zakonnych. Jego projekt wiąże się $\mathrm{z}$ historią sygnalizowanego funduszu pomocowego. Minister spraw wewnętrznych Dmitrij N. Błudow, po silnych naciskach bp Josifa Siemaszki (i postaci zbliżonych do Murawiowa), zasiadającego uprzednio jako asesor w Kolegium katolickim, zaproponował kolejnemu carowi Mikołajowi I kasatę 191 domów zakonnych i klasztorów łacińskich, która nastąpiła w $1832 \mathrm{roku}^{16}$. Wówczas doszło do znacznego powiększenia funduszu pomocowego o kwoty pochodzące z zasobów majątkowych zlikwidowanych klasztorów. W 1837 roku fundusz dysponował już kwotą 178989 rb. 10 kop. w srebrze, a po wspomnianej kasacie zakonów wpłynęło ponadto 254845 rb. 68 kop. Stąd pod koniec wspomnianego 1837 roku fundusz pomocowy wynosił już 433834 rb. 78 kop. w srebrze i nadal wzrastał za sprawą nowych pomysłów MSW aprobowanych przez cara w następnych latach (por. tabela 1.) ${ }^{17}$.

Tabela 1. Kapital funduszu pomocowego w latach 1826-1908 ${ }^{18}$ The capital of the assistance fund in the years 1826-1908

\begin{tabular}{|c|c|}
\hline Rok/year & Suma kapitalu (ruble srebrne)/ capital sum (silver rubles) \\
\hline $\mathbf{1}$ & $\mathbf{2}$ \\
\hline 1826 & 18080 \\
\hline 1828 & 34789 \\
\hline
\end{tabular}

${ }^{11}$ РГИА, ф. 822, оп. 1, д. 2712. Wartość 1 rubla w srebrze wynosiła w asygnacjach 3,60 rb.; por. ПСЗ, ч. II, т. 7, nr 5709.

${ }^{12}$ ПСЗ, ч. II, т. 4, $\mathrm{nr} 2892$.

${ }^{13}$ Jak N. Karamzin, A. Puszkin i inni, zob.: Nowak, Geneza Powstania, passim.

${ }_{14}^{4}$ Четыре записки графа М. Н. Муравьева о Северо-Западном крае (1830-1865), „Русский Архив", 6 (1885) s. 161.

${ }^{15}$ РГИА, ф. 821, оп. 125, д. 547, k. 153-162.

${ }^{16}$ РГИА, ф. 822, оп. 1, д. 5237a. Klasztory bazyliańskie likwidowano stopniowo już od roku 1795. Por. M. Radwan, Carat wobec Kościoła greckokatolickiego w zaborze rosyjskim 1796-1839, Roma-Lublin 2001, s. 76-143.

${ }^{17}$ РГИА, ф. 821, оп. 125 , д. 543, k. 4.

${ }^{18}$ РГИА, ф. 821, оп. 125, д. 543; ф. 822, оп. 1, д. 2712; por.: A. Szelążek, Podstawy dotacji duchowieństwa katolickiego w Polsce w okresie przedkonkordatowym, Toruń 1947, s. 113. 


\begin{tabular}{|c|c|}
\hline $\mathbf{1}$ & $\mathbf{2}$ \\
\hline 1842 & 1576214 \\
\hline 1864 & 2122971 \\
\hline 1908 & 6423865 \\
\hline
\end{tabular}

Mikołaj I w 1842 roku zdecydował się na kolejny antykościelny krok - kasatę beneficjów diecezjalnych, zakonnych, parafialnych i wyznaczył sposób wynagradzania wymienionych instytucji i osób ${ }^{19}$. Wówczas car uzasadniał swoje postępowanie w następujący sposób: „Pragnęliśmy [...] zagwarantować utrzymanie duchowieństwu i uwolnić je od bezpośredniego zajmowania się majątkami, co odwleka je od świętych obowiązków należących do stanu duchownego i dlatego postanowiliśmy przekazać wszystkie tego rodzaju dobra Ministerstwu Majątków Państwowych" ${ }^{20}$. Znacjonalizowane beneficja zostały przekazane zgodnie z wolą monarchy, ale z zastrzeżeniem: część oprocentowania miała wystarczyć na opłacenie działalności parafii i duchowieństwa, pozbawionych beneficjów. Nie ujawniono nigdzie jaką wartość posiadały znacjonalizowane majątki kościelne. Według obliczeń bpa Adolfa Szelążka, fundusz duchowieństwa świeckiego i zakonnego - ziemia, nieruchomości, kapitał - zabrany przez rząd rosyjski w wieku XIX wynosił $171745726 \mathrm{rb} .{ }^{21}$ Jednak wspomniany autor nie ustalił jaki był coroczny przychód ze skasowanych majątków.

Kolejne ukazy carskie (1 I 1842, 10 V 1843, 18 VI 1843, 7 IV 1856, 28 V 1862) udowadniały, że beneficja kościelne nie zostały skonfiskowane lecz przekazane w zarząd państwowy. $Z$ tego też powodu rząd zatrzymywał dla siebie $10 \%$ od dochodów jako wynagrodzenie za zarządzanie majątkami. W praktyce jednak te beneficja, ,za wyjątkiem lasów, zostały po części rozdarowane, po części rozprzedane, budżet zaś kościelny nie ulegał powiększeniu, ale miał tendencję zmniejszania się"22.

Rząd również samowolnie, bez żadnych uzasadnień, stwierdził że na pokrycie kosztów utrzymania byłych beneficjentów, pozbawionych dochodowych dóbr i funduszy potrzebna jest kwota 578791 rubli. Ten tzw. mikołajewski kredyt, minister wyznań Rządu Tymczasowego Anton W. Kartaszew (1875-1960) w 1917 roku uznał za sumę znacznie zaniżoną i upoważniającą episkopat katolicki do jej zakwestionowania ${ }^{23}$. Zaznaczono jednak, że jeśli po wypłaceniu należnych kwot parafiom i innym adresatom, jak niektórym zachowanym klasztorom, pozostaną jakieś kwoty, to należy je przekazać na fundusz pomocowy, którym dysponuje Kolegium katolickie. Jak zaznacza wspomniany Kartaszew, wymieniony kredyt coroczny - 578791 rubli - był regularnie przyznawany od 1843 do 1917 r. Saldo z niewydanych sum było przekazywane do tzw. funduszu czyli kapitału pomo-

${ }^{19}$ ПСЗ, ч. II, т. 18, nr 15189.

${ }^{20}$ Tamże.

${ }^{21}$ Szelążek, Podstawy dotacji duchowieństwa katolickiego w Polsce, s. 65.

22 РГИА, ф. 821, оп. 128, д. 1740 (w oryginale tekst w języku polskim).

${ }^{23}$ РГИА, ф. 822, оп. 11, д. 592, k. 78-122. W komisji pracującej z Kartaszewem nad tymi problemami, ze strony katolickiej współpracował późniejszy premier polski W. Grabski (1874-1938), uprzednio poseł do Dumy. 
cowego. O rozmiarach manipulacji finansowych władz może świadczyć bardzo ogólna i nieprecyzyjna wiadomość z końca XIX w., że po wszystkich kasatach w dyspozycji Kolegium znalazło się 150500 dusz męskich oraz kapitał w wysokości $5160000 \mathrm{rbs}$. Suma ta była oprocentowana i corocznie przynosiła dodatkowo $697211 \mathrm{rbs}$. dochodu ${ }^{24}$. To pozwoliło władzom na kolejne nadużycie - od 1867 roku Departament Wyznań Obcych MSW zabierał regularnie 15002 rb. na swe cele - wypłaty urzędników, nagrody finansowe, dofinansowania emerytur itp. ${ }^{25}$ Urząd kierujący antykościelną polityką w poważnym stopniu był finansowany ze źródeł kościelnych. „Na pokrycie wydatków Kasy Państwa z powodu utrzymania urzędów dla spraw wyznania rzymsko-katolickiego" w 1917 roku przyznawano $72979 \mathrm{rb}^{26}$.

Aktywność finansowa Kościoła w Rosji poszła więc dwoma torami - z jednej strony gwarantowano utrzymanie stałe instytucjom $i$ ich personelowi, a $z$ drugiej $\mathrm{z}$ tzw. funduszu pomocowego ${ }^{27}$ można było finansować wybrane inicjatywy.

\section{Finansowanie parafii i duchowieństwa}

Cytowana już publikacja rosyjskiego Departamentu Wyznań Obcych MSW28 przedstawia wysokość wydatków wypłacanych wprawdzie z zasobów skarbu państwa, ale faktycznie pochodzących z byłych dóbr kościelnych, przejmowanych na różne sposoby przez władze na terenach tzw. guberni zachodnich, anektowanych w wyniku rozbiorów Rzeczypospolitej. W 1853 roku, kiedy wspomniana publikacja ukazała się drukiem, kwota przeznaczona na pokrycie kosztów utrzymania parafii, duchowieństwa we wszystkich diecezjach, kurii, seminariów, wynosiła łącznie 453783 ruble. Nie wiadomo jednak, na jakim poziomie pozostawał faktyczny odsetek od kwot gotówkowych i byłych majątków kościelnych oraz sum $\mathrm{z}$ tego przeznaczonych na tzw. fundusz pomocowy. Wiadomo tylko, że w roku 1864 posiadał on już 2122971 rubli $^{29}$, a narastał z dodawania sald pozostałych z tzw. stałego kredytu, jak zaznaczono wynoszącego $578791 \mathrm{rb}$. Dalsze powiększanie tej kwoty zależało od resztek na rachunkach rozliczających świadczenia dla wszystkich diecezji w latach następnych.

Wymieniona w 1853 roku suma 453783 rubli, powstała z podliczenia wydatków dla wszystkich diecezji, nie jest pełna. Wydaje się, że poziom zaniżenia podawanych sum nie przekracza paru procent. Wydawca cytowanej publikacji zaznacza, że w niektórych przypadkach nie dysponował potrzebnymi informacjami. Dla metropolitalnej archidiecezji mohylewskiej obliczona kwota wyniosła 60680 rubli, w tym 13410 na rzecz ordynariusza, kurii i kapituły, 38430 dla

${ }^{24}$ РГИА, ф. 821, оп. 125, д. 547, k. 156.

${ }^{25}$ Tamże.

${ }^{26}$ Szelążek, Podstawy dotacji duchowieństwa katolickiego w Polsce, s. 114.

${ }^{27}$ Ponadto w 1846 r. oddzielono od funduszu 300000 rb. i utworzono kapitał budowlany. Z tej puli pieniędzy finansowano budowy i remonty obiektów sakralnych. W styczniu 1918 roku wynosił on 375758 rb. 40 kop. РГИА, ф. 821, оп. 128, д. 1740, k. 15

${ }_{28}^{28}$ Список римско-католических духовных лии и учреждений, С.Петербург 1853.

${ }^{29}$ РГИА, ф. 821, оп. 125, д. 543, k. 6. 
parafii, 6360 dla klasztorów męskich oraz 2480 dla żeńskich ${ }^{30}$. W podobny sposób skonstruowana należność dla diecezji wileńskiej wyniosła 129430 rb., dla diecezji telszewskiej 95745 rb., dla mińskiej 55630 rb., dla łucko-żytomierskiej 67590 rb., dla kamienieckiej 33645 rb. ${ }^{31}$ Dla diecezji tyraspolskiej, dopiero się organizującej, nie mającej jeszcze ani kapituły ani klasztorów przewidziano tylko 11063 ruble $^{32}$. Zapewne z czasem ustalone kwoty zmieniały się z powodu dalszej kasaty klasztorów, a także późniejszej likwidacji diecezji mińskiej i kamienieckiej. W 1913 roku bowiem budżet dochodów i wydatków MSW przewidywał na utrzymanie duchowieństwa $\mathrm{w}$ imperium rosyjskim $491776 \mathrm{rb}{ }^{33}$

Zgodnie z rozporządzeniem carskim MSW miało przeznaczać (rok 1862) 578791 rubli srebrnych na utrzymanie duchowieństwa - czyli także kościelnych instytucji ${ }^{34}$. Nie wydane resztki z tej kwoty miały być przekazywane na konto tzw. funduszu pomocowego. Należy sądzić, że z wymienionej sumy należało wypłacać nie tylko należności zgodnie z przypisanymi klasami poszczególnym parafiom, klasztorom i biskupom diecezjalnym, ale także celebransom zobowiązanym do odprawiania intencji zamówionych kiedyś przez fundatorów.

Skarb państwa przejąwszy już w 1832 r. dobra skasowanych klasztorów został zobowiązany do zabezpieczenia wieczystych zapisów duchownych na ich rzecz w postaci mszy świętych i innych obrzędów religijnych, jakie zakonnicy przyobiecali spełnić przyjmując od fundatorów odpowiednie ofiary w postaci ziem lub pieniędzy w gotówce. Dokumentacja archiwalna wieczystych mszy i innych nabożeństw zamawianych w klasztorach skasowanych od roku 1832 nie ma jednolitego charakteru. Stąd trudno opracować całościowe podsumowanie. Jednak niektóre diecezje przedstawiały szczegółowo tę kwestię. Biskup Mateusz Lipski, ordynariusz miński referował, że 30 skasowanych klasztorów posiadało kapitał funduszowy - tylko częściowo pewny, a częściowo kwestionowany przez spadkobierców lub arendarzy ${ }^{35}$. Fundusz pewny wynosił 199659 rbs. 53,20 kop., 1534 rb.asygn. 36 kop., 12473 czerwońce i pewną, nieznaczną ilość annuat pieniężnych. Wymienione sumy pewne po oprocentowaniu przynosiły rocznie 11665 rbs. 75,5 kop., w asygnatach 75 rb., 10,5 kop. oraz 752 czerwońce 87 kop. Na pokrycie należności na coroczne zobowiązania mszalne należało się 4472 rbs. 54 kop. oraz 36 czerwońców. Po potrąceniu tych kwot z uzyskiwanych odsetek, pozostaje wysokie saldo - 7466 rbs., 20,5 kop., 78 rb.asygn. 10,5 kop., 716 czerw. 87 kop. Saldo to w całości miało zostać przekazane do kapitału pomocowego.

$\mathrm{Z}$ nieco inaczej skonstruowanej informacji o diecezji łucko-żytomierskiej dowiadujemy się, że pewny kapitał funduszowy byłych klasztorów w $1832 \mathrm{r}$. wynosił 307348 rbs. 69 kop. oraz 750 czerwońców ${ }^{36}$. Odsetki od tych sum miały pokryć honoraria za 17221 cichych intencji mszalnych, 1259 śpiewanych oraz 158

\footnotetext{
${ }^{30}$ Список, s. 4-40.

31 Tamże, s. 41-218.

${ }^{32}$ Tamże, s. 219-230.

${ }^{33}$ Szelążek, Podstawy dotacji duchowieństwa katolickiego w Polsce, s. 114-115.

${ }^{34}$ ПСЗ, ч. II, т. 37, nr 38323.

${ }_{35}$ РГИА, ф. 822. оп. 11, д. 702.

${ }^{36}$ РГИА, ф. 822, оп. 11, д. 699.
} 
nabożeństw żałobnych. Jakiej wielkości miało być saldo przekazane na fundusz pomocowy nie udało się ustalić.

Ze sprawozdania z diecezji wileńskiej, pochodzącego z 1842 r., dotyczącego 50 skasowanych klasztorów wynika, że posiadały one następujące kapitały fundacyjne: 388838 rbs. 94,5 kop., 1622 czerwońce i 4342 talarów, nie licząc drobnych kwot, annuat i dziesięcin ${ }^{37}$. Odsetki od podanych sum miały posłużyć na zamówienie 19110 mszy św. i 251 nabożeństw żałobnych, nie licząc ponadto specjalnych litanii. Autor wileńskiego sprawozdania określa także gdzie i na jakich warunkach miały być odprawiane obrzędy obciążające skasowane klasztory. Honorarium zaś za msze św. miało wynosić 30 kop., za nabożeństwo żałobne 3 rb. 50 kop. Warto zaznaczyć przykładowo, że po skasowanym dominikańskim klasztorze w Wysokim Dworze (1128 intencji mszalnych rocznie), 500 mieli odprawić zakonnicy z klasztoru Św. Ducha w Wilnie, a 128 na Łukiszkach, pozostałe w pobliskich parafiach diecezjalnych. Intencje z byłego klasztoru karmelitańskiego w Antoleptach - 1001 rocznie - miała przejąć miejscowa poklasztorna parafia, Ostra Brama, Łukiszki i pobliskie kościoły. Po grodzieńskich dominikanach rocznie 2076 intencji - ich obowiązki miały spaść na wileński klasztor Św. Ducha, poklasztorną parafię grodzieńską i tamtejszy klasztor bernardyński ${ }^{38}$. Podobnie zostały rozpisane inne nabożeństwa przewidziane w umowach $\mathrm{z}$ dobroczyńcami.

Wyjątkowo skąpa relacja o 13 klasztorach skasowanych w diecezji kamienieckiej w 1832 r. podaje, że ich kapitały funduszowe przeznaczone na wieczyste msze wynosiły 42753 rbs. i 20 czerwońców ${ }^{39}$. Brak jednak danych o wysokości otrzymywanego oprocentowania i zobowiązań wobec ofiarodawców. Nie można także określić salda, jakie miałoby przejść do kapitału pomocowego, po pokryciu umownych zobowiązań. W ostatniej diecezji - telszewskiej - w 1832 r. skasowano tylko sześć klasztorów, posiadających pewne fundusze 40321 rbs. 19,25 kop., 2488 czerwońców, 2513 talarów ${ }^{40}$. Przynosiły one rocznie oprocentowania 2243 rbs. 76 kop., 148 czerwońców i 150 talarów. Na pokrycie zobowiązań fundacyjnych, zaciągniętych wobec ofiarodawców, wystarczało 840 rbs. 65 kop., 30 czerwońców i jeden talar. Coroczne saldo z tego pełnego oprocentowania, po wypłaceniu należnych honorariów celebransom, wynosiło 1403 rbs. 11 kop., 112 czerwońców i 149 talarów. Zgodnie z decyzją carską przechodziło ono do funduszu pomocowego. Wprawdzie nie podano pełnej liczby intencji mszalnych pozostałych po skasowanych wspólnotach zakonnych, ale zaznaczono na jakich warunkach finansowych należało je przekazywać innym klasztorom lub parafiom ${ }^{41}$.

Każda diecezja, raczej w sposób nieujednolicony prezentowała w raportach do Kolegium wysokość tzw. funduszy duchownych, czyli mających pokrywać należności za zamówione intencje. Księgowy tej instytucji w 1908 r. oświadczył, że kapitał ten wynosił 1190730 rubli, a coroczne odsetki od niego wystarczające za

${ }^{37}$ РГИА, ф. 822, оп. 11, д. 711, k. 49.

38 Tamże, k. 13.

${ }^{39}$ РГИА, ф. 822, оп. 11, д. 700.

${ }^{40}$ РГИА, ф. 822, оп. 11, д. 706.

${ }^{41}$ РГИА, ф. 822, оп. 4, д. 18155 а, б, в, г: О рассылке процентов от фундушевых сумм, 1880 год. 
pokrycie obowiązkowych honorariów za odprawione nabożeństwa wyniosły 46 $325 \mathrm{rubli}^{42}$. Jak zaznaczono już wyżej, odsetki te z reguły były wyższe, co pozwalało władzom pozostałe saldo wykorzystać według swego uznania. Odszukane archiwalia wymagają bliższej lektury. Zachowało się bowiem sporo dokumentów potwierdzających zamawianie odpowiednich intencji przez Kolegium i rozsyłanie należnych honorariów ${ }^{43}$.

$\mathrm{Z}$ powyższej prezentacji postępowania władz z testamentalnymi zapisami zobowiązań duchownych zaciągniętych przez zakony jednoznacznie widoczna jest kolejna samowola strony państwowej. Przekazywanie salda z oprocentowanego kapitału zakonnego do dyspozycji Kolegium katolickiego było jawnym nadużyciem prawnym i moralnym, a zarazem symptomatycznym dla lokalnego cezaropapizmu. Pozbawiano częściowo prawnych honorariów należących się celebransom odprawianym zamówione intencje mszalne. Tym sposobem wzrastał tzw. fundusz pomocowy duchowieństwa. Jak już zaznaczono, w 1864 r. wynosił on 2122971 rubli w srebrze, w 1888 był już na poziomie 3922175 rb., a w roku 1908 doszedł do 6423865 rubli, 7 kop. ${ }^{44}$ Kwoty te zdeponowane w Banku Państwowym od 1895 r. corocznie przynosiły odsetki, które przekazywano do dyspozycji Rzymsko-katolickiego Kolegium Duchownego.

W petersburskich archiwach, wstępnie udało się określić wydatki nadzwyczajne i zwyczajne faktycznie pokrywane przez Ministerstwo Skarbu, ale za pośrednictwem Departamentu Wyznań Obcych oraz Kolegium. Bliżej zostaną ukazane - w przekroju chronologicznym - operacje nadzwyczajne $\mathrm{z}$ lat 1842-1852 oraz 1870-1880 oraz jednoroczne z 1889 roku $^{45}$. Natomiast coroczne zwyczajne wydatki na utrzymanie duchowieństwa i instytucji kościelnych były finansowane z osobnej puli - 578791 rubli, które tu nie będą szczegółowo referowane.

\section{Wydatki nadzwyczajne $\mathrm{z}$ funduszu pomocowego w latach 1842-1852}

Odnotowano poniżej tylko nadzwyczajne operacje finansowe (od $1000 \mathrm{rb}$. wzwyż, nie licząc drobnych kwot), które z upoważnienia monarchy, przeprowadziło MSW za pośrednictwem Kolegium rzymskokatolickiego w latach 18421852. Dotyczyły one m.in. zakupów i adaptacji budynków dla Akademii Duchownej i Kolegium, remontów siedzib biskupów.

42 РГИА, ф. 821, оп. 125, д. 543, k. 232.

${ }^{43}$ РГИА, ф. 822, оп. 4, д. 18872, д. 19165, 19299; оп. 5, д. 19450, 20022.

${ }^{44}$ РГИА, ф. 821, оп. 125, д. 543, k. 227.

45 Wydatki i dochody Departamentu Wyznań Obcych MSW były corocznie publikowane w seryjnym wydawnictwie MSW pt.: Смета доходовъ, расходовъ и спеціальныхъ средствъ по ведомству Духовныхъ Делъ Иностранныхъ Исповеданій. 
Tabela 2. Wydatki nadzwyczajne/ Special expenses

\begin{tabular}{|c|c|c|}
\hline Lp & Tytul zakupu/ the title of the purchase & Kwota/sum \\
\hline 1. & $\begin{array}{l}\text { Kupno budynku byłej Rosyjskiej Akademii Nauk } \\
\text { z przeznaczeniem dla Akademii Duchownej przenoszonej } \\
\text { z Wilna }(1842)^{\mathrm{a}}\end{array}$ & $70000 \mathrm{rb}$. \\
\hline 2. & $\begin{array}{l}\text { Przebudowa zakupionego budynku na potrzeby Akademii } \\
(1842)^{\mathrm{b}}\end{array}$ & $168830 \mathrm{rb}$. \\
\hline 3. & $\begin{array}{l}\text { Zakupienie b. domu G. Dierżawina na siedzibę Kolegium } \\
(1848)^{c}\end{array}$ & $86000 \mathrm{rb}$. \\
\hline 4. & Adaptacja powyższego domu na potrzeby Kolegium ${ }^{\mathrm{d}}$ & $15000 \mathrm{rb}$. \\
\hline 5. & Honoraria za bulle nominacyjne biskupów ${ }^{\mathrm{e}}$ & $9271 \mathrm{rb}$. \\
\hline 6. & Przebudowa domu Kolegium $(1848-1854)^{\mathrm{f}}$ & $165000 \mathrm{rb}$. \\
\hline 7. & Dokończenie budowy kościoła w Odessie & $25000 \mathrm{rb}$. \\
\hline 8. & Budowy gospodarcze kurii żytomierskiej & $4560 \mathrm{rb}$. \\
\hline 9. & Adaptacja mieszkania metropolity I. Hołowińskiego ${ }^{g}$ & $2000 \mathrm{rb}$. \\
\hline 10. & Remont seminarium kamienieckiego & $10833 \mathrm{rb}$. \\
\hline 11. & $\mathrm{Na}$ jednorazowe potrzeby domu Kolegium & $3060 \mathrm{rb}$. \\
\hline 12. & Remont seminarium wileńskiego & $3608 \mathrm{rb}$. \\
\hline 13. & Remont domu biskupa telszewskiego & $5000 \mathrm{rb}$. \\
\hline \multirow[t]{2}{*}{14.} & Remonty pomieszczeń przy katedrze w Mińsku ${ }^{\mathrm{h}}$ & $7004 \mathrm{rb}$. \\
\hline & Razem & 575166 rb. \\
\hline
\end{tabular}

Z powyższego zestawienia nadzwyczajnych wydatków wyraźnie widać jak poważne kwoty przeznaczono na osadzenie Akademii Duchownej w stolicy kraju, z dala od buntowniczego Wilna, gdzie nadal pamiętano filomatów, filaretów, insurekcję kościuszkowską, Jasieńskiego, Konarskiego. Jak zaznacza Bronisław Ussas na kupno wspomnianego budynku ,rząd carski [...] nie wydał ani grosza pieniędzy ze skarbu rosyjskiego" ${ }^{46}$. Pieniądze na adaptację byłego gmachu Rosyjskiej Akademii Nauk na potrzeby Akademii Duchownej przesyłano w 31 transzach w okresie od czerwca 1842 do czerwca 1844 r. Sumy wielkości od 1000 do 10000 rb głównie pochodziły z kapitałów skasowanych klasztorów. Na przykład kwota 6000 rb wypłacona Akademii w listopadzie 1843 r. składała się z kapitałów

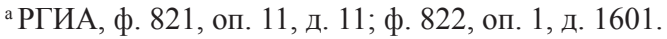

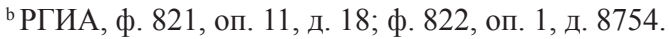

' РГИА, ф. 821, оп. 11, д. 21; ф. 822, оп. 2, д. 10842.

${ }^{ }$РГИА, ф. 821, оп. 11, д. 23; ф. 822, оп. 2, д. 10535.

е РГИА, ф. 821, оп. 11, д. 24.

fРГИА, ф. 822, оп. 4, д. 11189.

g РГИА, ф. 821, оп. 11, д. 26.

${ }^{\text {h } Р Г И А, ~ ф . ~ 821, ~ о п . ~ 11, ~ д . ~} 27$.

${ }^{46}$ B. Ussas, Z dziejów grabieży i niszczenia polskiego mienia kościelnego przez Rosjan w świetle świadectw rosyjskich (1655-1925), „Przegląd Powszechny”, t. 210, 1936, s. 56. Por. aprobatę Mikołaja I dla projektu ministra spraw wewnętrznych: РГИА, ф. 821, оп. 11, д. 17: О покупке на счет вспомогательного капитала р.к. духовенства здания б. Российской Академии. 
zlikwidowanych w 1832 roku klasztorów diecezji łucko-żytomierskiej, a kolejna (5 XII) pochodziła od dominikańskich wspólnot Grodna i Ostrowca, bernardyńskich z Głuska, Mińska i Pińska, benedyktyńskiej z Mińska, franciszkańskiej z Baru, kapucyńskiej z Dunajowiec i trynitarskiej w Szumbaru ${ }^{47}$. Nie można także pominąć faktu, że analogiczna akademia prawosławna w stolicy dysponowała niemal dwukrotnie wyższym budżetem, a najlepiej opłacanymi profesorami byli wykładowcy historii Rosji i literatury, zgodnie z postulatem przyśpieszonej rusyfikacji głoszonej przez słowianofilów.

\section{Wydatki funduszu pomocowego w latach 1870-1880}

Nadzwyczajne wydatki Kolegium w latach 1842-1852 zostały utrzymane niemal na takim samym poziomie w innych okresach. Dla porównania przytoczymy wydatki z lat 1870-1880. Wiążą się one z dalszą centralizacją nadzoru nad Kościołem łacińskim. Pod koniec lat 60 . warszawska metropolia została podporządkowana petersburskiemu Kolegium Duchownemu i została zobowiązania do posiadania swych asesorów w jego składzie ${ }^{48}$. W tymże okresie zlikwidowano Warszawską Akademię Duchowną. Przeniesienie jej studentów do Petersburga miało na celu oderwanie katolickiego środowiska intelektualnego od rodzimego i od dawnych ziem zabranych, zdominowanych przez kulturę polską. Zdaniem słowianofilów, rusyfikacja polskiego kleru w stolicy była bardziej obiecująca ${ }^{49}$. Bez wahania warszawskiej metropolii polecono partycypacje w różnego typu wydatkach na terenie cesarstwa rosyjskiego jak i poza jego granicami ${ }^{50}$.

W tychże latach finansowano m.in.

1. Budowa katedry i kurii metropolitalnej w Petersburgu (1870)

2. Porządkowanie archiwaliów skasowanej diecezji kamienieckiej $(1870)^{b}$

3. Przebudowa klasztoru pofranciszkańskiego w Kownie na szpital $(1870)^{\mathrm{c}}$

4. Kwota przekazana do dyspozycji generał-gubernatora Kraju Południowo-Zachodniego (1871)
$300000 \mathrm{rb}$.

$1329 \mathrm{rb}$.

$12000 \mathrm{rb}$.

$5000 \mathrm{rb}$.

а РГИА, ф. 822, оп. 4, д. 16851.

' РГИА, ф. 821, оп. 11, д. 45.

${ }^{\mathrm{c}}$ Tamże.

${ }^{47}$ РГИА, ф. 822, оп. 2, д. 8601, k. 281-410. Ogółem najwięcej pieniędzy na przebudowę wydano z kapitałów grodzieńskiego klasztoru dominikanów - 11667 rb. 94 kop.

${ }^{48}$ Badaniami nad uposażeniem Kościoła w Królestwie Polskim zajmował się bp A. Szelążek. W oparciu o materiały archiwalne wydał szereg publikacji w tym: Podstawy dotacji duchowieństwa katolickiego w Polsce w okresie przedkonkordatowym, Toruń 1947. Zob. także: M. Dębowska, Badania biskupa Adolfa Piotra Szelążka nad majątkiem i uposażeniem duchowieństwa na ziemiach polskich, „Archiwa Biblioteki i Muzea Kościelne” (dalej: ABMK), 74 (2000) s. 49-62.

49 I. Wodzianowska, Rzymskokatolicka Akademia Duchowna w Petersburgu, Lublin 2007, s. 25 .

50 Na przykład w 1900 r. nakazano wpłacić 67586 rbs. na koszt budowy trzeciego piętra w siedzibie Kolegium Duchownego (ul. Fontanka 118), a równocześnie 15000 rb. na rozbudowę hospicjum przy kościele pw. św. Stanisława w Rzymie, którym zarządzało Kolegium i mianowało tam duszpasterzy. W następnym roku fundusz hospicjum zasiliło kolejne 20000 rbs. РГИА, Ф. 821, оп. 11, д. 75,76 . 
5. Remont kościoła św. Anny i św. Michała (bernardynek) w Wilnie (1871)

6. Budowa katedry metropolitalnej w Petersburgu (1871)

7. Wydatki szkoły organistowskiej w Mińsku (1871)

8. Suma oddana do dyspozycji gubernatora mińskiego (1871)

9. Pensja biskupa J. Iwaszkiewicza $(1871)^{\mathrm{d}}$

10. Kwota oddana do dyspozycji generał-gubernatora kijowskiego (1872)

11. Dodatek do pensji biskupa Aleksandra Gintowta $(1872)^{\mathrm{e}}$

12. Nieprzewidziane wydatki Kolegium katolickiego $(1873)^{\mathrm{f}}$

13. Utrzymanie kurii metropolitalnej (1873)

14. Dofinansowanie katedry metropolitalnej (1873)

15. Dofinansowanie seminarium płockiego (1873)

16. Remont i dofinansowanie seminarium wileńskiego $(1873)^{\mathrm{g}}$

17. Remont klasztoru mariawitek w Witebsku (1873)

18. Na potrzeby szkoły parafialnej w Helsinkach (1873)

19. Dofinansowanie seminarium tyraspolskiego (1873)

20. Zasiłek jednorazowy dla biskupa Wincentego Lipskiego $(1873)^{\mathrm{h}}$

21. Kupno domu dochodowego w Wilnie $(1874)^{\mathrm{i}}$

22. Na koszty utrzymania seminarium w Petersburgu $(1874)^{\mathrm{j}}$

23. Adaptacja domu, zakupionego dla Akademii Duchownej $(1874)^{\mathrm{k}}$

24. Remont kościoła w Puławach (Nowa Aleksandria) (1874)

25. Utrzymanie Kolegium Rzymsko-katolickiego (1874)

26. Koszta mebli do parafii w Helsinkach $(1875)^{1}$

27. Zasiłek dla biskupa Aleksandra Bereśniewicza $(1875)^{\mathrm{m}}$

28. Budowa kościoła w Poniewieżu $(1876)^{\mathrm{n}}$

29. Remont kościoła w Jezno $(1876)^{\circ}$

30. Kwota dyspozycyjna dla generał-gubernatora kijowskiego (1876)

$24406 \mathrm{rb}$.

$40000 \mathrm{rb}$.

$1200 \mathrm{rb}$.

$2000 \mathrm{rb}$

$2000 \mathrm{rb}$.

$3000 \mathrm{rb}$.

$2000 \mathrm{rb}$

$1200 \mathrm{rb}$.

$10000 \mathrm{rb}$.

$1590 \mathrm{rb}$

$1000 \mathrm{rb}$.

$25920 \mathrm{rb}$.

$4127 \mathrm{rb}$

$2500 \mathrm{rb}$.

$8442 \mathrm{rb}$.

$1500 \mathrm{rb}$.

$6000 \mathrm{rb}$.

$14000 \mathrm{rb}$.

$140000 \mathrm{rb}$.

$9812 \mathrm{rb}$.

$9000 \mathrm{rb}$

$1000 \mathrm{rb}$.

$1000 \mathrm{rb}$

$6000 \mathrm{rb}$.

$4000 \mathrm{rb}$.

$5000 \mathrm{rb}$.

d РГИА, ф. 821, оп. 11, д. 46.

е РГИА, ф. 821, оп. 11, д. 47.

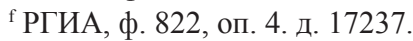

g РГИА, ф. 822, оп. 4, д. 17278.

h РГИА, ф. 821, оп. 11, д. 48.

'РГИА, ф. 822, оп. 4, д. 17382.

ј РГИА, ф. 821, оп. 11, д. 49.

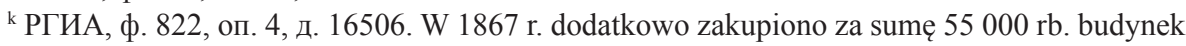
sąsiadujący z gmachem Akademii (ф. 822, оп. 4, д. 16506), a w latach następnych przystąpiono do jego adaptacji.

${ }^{1}$ РГИА, ф. 822, оп. 4, д. 17369.

m РГИА, ф. 821, оп. 11, д. 50.

${ }^{n}$ РГИА, ф. 822, оп. 4, д. 16918.

${ }^{\circ}$ РГИА, ф. 822, оп. 4, д. 17677. 
31. Honorarium dla autora historii Kościoła katolickiego $(1876)^{\mathrm{p}}$

$1000 \mathrm{rb}$.

32. Remont kościoła w Dorpacie $(1877)^{\mathrm{r}}$

$4000 \mathrm{rb}$.

33. Dofinansowanie katedry w Petersburgu (1877)

$1000 \mathrm{rb}$.

34. Zasiłek dla biskupa Gintowta (1877) ${ }^{\mathrm{s}}$

$1000 \mathrm{rb}$.

35. Adaptacja domu b. gubernatora Petersburga pod seminarium duchowne (1878-1888) ${ }^{t}$

$103000 \mathrm{rb}$.

36. Remont budynku Kolegium (1879) ${ }^{\mathrm{u}}$

$11978 \mathrm{rb}$.

37. Remont katedry w Kownie (1879)w

$17150 \mathrm{rb}$.

38. Dofinansowanie seminarium wileńskiego $(1880)^{\mathrm{z}}$

$4000 \mathrm{rb}$.

Razem

789154 rb.

Przytoczony katalog nadzwyczajnych operacji finansowych Kolegium w latach 1870-1880 potwierdza i tym razem - nacisk na pełną kontrolę instytucji kościelnych i naukowych przez władze centralne kraju. W zasięgu ręki mieli być zarówno metropolita, jego kuria jak i seminarzyści oraz studenci akademii duchownej. Te pozycje były finansowane w pierwszej kolejności. Ponadto bez żadnej żenady oddawano także kościelne pieniądze do dyspozycji rosyjskich gubernatorów - kijowskiego, wileńskiego i mińskiego (rzekomo na potrzeby duchowieństwa). Niemal 20 lat później z polecenia MSW dokonano jeszcze jednej wyjątkowo ważnej operacji finansowej - podjęto przygotowania do przeniesienia (bez pytania Kurii Rzymskiej) dotychczasowej kurii metropolitalnej w Petersburgu z ul. Pierwszej roty 11 na ul. Fontanki 118, gdzie już funkcjonowało Kolegium Duchowne. Na opuszczone miejsce po kurii przeniesiono seminarium duchowne (z dzisiejszej ul. Rimskogo Korsakowa 49). Koszty tej operacji wyniosły 250000 rb. ${ }^{51}$.

Przytoczone zestawienie milczeniem pomija szczególne dofinansowanie polityki rusyfikacyjnej w parafiach diecezji mińskiej. Z wnioskiem takim wystąpiła Komisja Rewizyjna ds. duchowieństwa katolickiego, a patronował jej głównie A. Mosołow, dyrektor Departamentu Wyznań Obcych, uległy mu biskup Józef Maksymilian Staniewski, wikariusz kapitulny mohylewski oraz ks. Piotr Żyliński, administrator narzucony przez N. Murawiowa diecezji wileńskiej (nigdy nie uznany przez Stolicę Apostolską) $)^{52}$. W diecezji mińskiej w latach 1871-1898, w różnych latach, presji rusyfikacyjnej w liturgii uległo około 24 duszpasterzy. Za taką służalczość byli oni dodatkowo wynagradzani pieniężnie ${ }^{53}$. Ponadto na ży-

р РГИА, ф. 821, оп. 11, д. 51.

r РГИА, ф. 822. оп. 4, д. 17677.

' РГИА, ф. 821, оп. 11, д. 52.

${ }^{\mathrm{t}}$ РГИА, ф. 821, оп. 11, д. 53; оп. 125, д. 543, k. 7; ф. 822, оп. 4, д. 20173.

" РГИА, ф. 821, оп. 11, д. 54.

w Tamże.

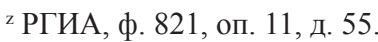

${ }^{51}$ РГИА, ф. 821, оп. 11, д. 75; оп. 125, д. 543, k. 7; ф. 822, оп. 4, д. 20173

52 Por. I. Wodzianowska, Przyczynek do biografii ks. Piotra Żylińskiego (1816-1887), ABMK, 86 (2006) s. 371-378.

${ }^{53}$ РГИА, ф. 821, оп. 11, д. 81; оп. 138, д. 24, k. 3-27. 
czenie ks. Ferdynanda Sęczykowskiego utworzono specjalną szkołę organistowską mającą upowszechniać śpiewy kościelne w języku rosyjskim. Cała ta akcja rusyfikacyjna w latach 1871-1898 kosztowała fundusz katolicki 241785 rbs $^{54}$.

Zasoby finansowe uszczupliły ponadto wyroki sądowe. Kolegium zostało zobowiązane na drodze sądowej (1884) wypłacić rodzinie Radziwiłłów $25200 \mathrm{rb}$., Trublewiczowi (1899) 18400 rb., Łuckiemu Towarzystwu Żydowskiemu (1903) 40000 rb. oraz hrabiemu Plater-Zyberkowi (1906) 1436000 rb. Poniesione straty wyniosły $227200 \mathrm{rbs}^{.5}$

\section{Operacje finansowe Kolegium w roku 1889}

Kolegium corocznie, oprócz wymienionych wyżej nadzwyczajnych wydatków, posiadało stałe wydatki m.in. na utrzymanie własnych budynków, kancelarii, konsystorza, seminariów duchownych i akademii, pensje urzędników, emerytury dla osób duchownych i świeckich. Na dzień 1 VIII 1888 Kolegium dysponowało w Banku Państwowym 3923175 rbs. Odsetki od tej kwoty wyniosły w roku następnym 198059 rubli 50 kop. Po doliczeniu do tej kwoty $26300 \mathrm{rb}$. pochodzących od zapóźnionych dłużników i 209 rb. 26 kop. odsetek od podręcznej gotówki będącej w dyspozycji zarządu Kolegium, mogło ono rozporządzać kwotą 224568 rbs. 78 kop. ${ }^{56}$ Kolegialny księgowy w cytowanym dokumencie przedstawił szczegółowo wydatki z 1889 roku, z funduszu pomocowego, zaznaczając za każdym razem podstawę prawną takich decyzji. Poniżej podajemy wykaz wydatków:

\begin{tabular}{|l|l|r|}
\hline 1. & $\begin{array}{l}\text { Utrzymanie Kolegium (remont budynku, } \\
\text { wynagrodzenie pracowników, ubezpieczenie } \\
\text { budynku, pensje architekta, nadzorcy, lekarza, } \\
\text { księgowego i jego pomocnika) }\end{array}$ & $23120 \mathrm{rb} .92 \mathrm{kop}$. \\
\hline 2. & $\begin{array}{l}\text { Utrzymanie Kapituły Mohylewskiej, konsystorza } \\
\text { oraz domu arcybiskupa }\end{array}$ & $16508 \mathrm{rb} .50 \mathrm{kop}$. \\
\hline 3. & Koszty utrzymania kancelarii metropolity & $1494 \mathrm{rb} .34 \mathrm{kop}$. \\
\hline 4. & Koszty finansowania Rzymsko-Katolickiej Akademii & $19845 \mathrm{rb} .00 \mathrm{kop}$. \\
\hline 5. & $\begin{array}{l}\text { Dofinansowanie katolickich seminariów: } \\
\text { w Petersburgu - } 14000 \text { rb., w Żytomierzu } 5650 \mathrm{rb} .,\end{array}$ & $20308 \mathrm{rb} .00 \mathrm{kop}$. \\
\hline 6. & Utrzymanie kościołów parafialnych i duchowieństwa & $26280 \mathrm{rb} .59 \mathrm{kop}$. \\
\hline 7. & Utrzymanie księży emerytowanych & $4500 \mathrm{rb} .00 \mathrm{kop}$. \\
\hline 8. & Utrzymanie księży karnie osadzonych w klasztorach & $3824 \mathrm{rb} .00 \mathrm{kop}$. \\
\hline 9. & Koszta wyjazdów służbowych duchowieństwa & $102 \mathrm{rb} .00 \mathrm{kop}$. \\
\hline 10. & $\begin{array}{l}\text { Koszty wyjazdów urlopowych studentów Akademii } \\
\text { Duchownej }\end{array}$ & $156 \mathrm{rb} .00 \mathrm{kop}$. \\
\hline 11. & Remont domów konsystorskich w Wilnie & $300 \mathrm{rb} .00 \mathrm{kop}$. \\
\hline 12. & Przygotowanie i rozesłanie olejów świętych & $199 \mathrm{rb} .00 \mathrm{kop}$. \\
\hline
\end{tabular}

\footnotetext{
${ }^{54}$ РГИА, ф. 821, оп. 125, д. 291, 296-297.

55 РГИА, ф. 821, оп. 125, д. 543, k. 226 v.

${ }^{56}$ РГИА, ф. 822, оп. 4, д. 18510 а, k. 65.
} 


\begin{tabular}{|c|c|c|}
\hline 13. & $\begin{array}{l}\text { Wynagrodzenie wicedyrektora Departamentu } \\
\text { Wyznań Obcych MSW, sekretarza i zasiłek dla } \\
\text { tegoż departamentu }\end{array}$ & 6780 rb. 00 kop. \\
\hline 14. & $\begin{array}{l}\text { Pensja rosyjskiego agenta w Rzymie (załatwiającego } \\
\text { rosyjską korespondencję ze Stolicą Apostolską). }\end{array}$ & 3000 rb. 00 kop. \\
\hline 15. & Pensja nauczyciela przy kościele w Mitawie & 133 rb. 00 kop. \\
\hline 16. & $\begin{array}{l}\text { Opłata pobrana przez Bank Państwowy za } \\
\text { przechowywanie dokumentacji finansowej }\end{array}$ & 376 rb. 95 kop. \\
\hline 17. & $\begin{array}{l}\text { Opłata bankowa wpłacona przy wymianie } \\
\text { terminowych talonów }\end{array}$ & $9661 \mathrm{rb} .45$ kop. \\
\hline 18. & $\begin{array}{l}\text { Kwota wysyłana corocznie na polecenie } \\
\text { Departamentu Wyznań Obcych }\end{array}$ & 125 rb. 00 kop. \\
\hline 19. & Dożywotnie emerytury osób świeckich & 10090 rb. 00 kop. \\
\hline 20. & Dożywotnie emerytury duchowieństwa & 13055 rb. 00 kop. \\
\hline \multirow[t]{4}{*}{21.} & $\begin{array}{l}\text { Dożywotnie emerytury wdów po byłych } \\
\text { pracownikach Kolegium }\end{array}$ & 5155 rb. 00 kop. \\
\hline & Stan wyjściowy kasy: & 224568 rb. 78 kop. \\
\hline & Wydano razem: & 165305 rb. 25 kop. \\
\hline & Saldo: & 59263 rb. 53 kop. \\
\hline
\end{tabular}

Kwota podana przez księgowego Kolegium w pozycji 6. wymienionego zestawienia znacznie powiększa budżet przewidywany w uprzednio cytowanej dokumentacji ${ }^{57}$. Warto niektóre wydatki przywołać. Na mocy carskiej decyzji z 14 IV 1848 roku przyznano dodatkowo diecezji mińskiej 2736 rb. 70 kop., a diecezjom wileńskiej, łucko-żytomierskiej i telszewskiej łącznie 10353 rb. 89 kop. (decyzja carska z 31 X 1851) i diecezji kamienieckiej 3695 rb. 96 kop. (decyzja z 8 IV 1859). Nie ujawniono jednak uzasadnienia tych postanowień. Tu także wymieniono należność dla katedry utworzonej w stolicy (1 000 rb.), której jeszcze nie było w 1853 roku. Natomiast niektóre kościoły zostały zaliczone do wyższej klasy, co oznaczało także podwyżkę w świadczeniach. Witebski kościół św. Antoniego przydzielono do pierwszej klasy, co upoważniało go do otrzymania 600 rubli rocznie, a kościół pofranciszkański w Udziale nieuznawany ${ }^{58} \mathrm{w} 1853 \mathrm{r}$., w 1889 zaliczony do piątej klasy, otrzymał 230 rubli.

W wykazie dożywotnich emerytur dla osób świeckich, na uwagę zasługuje pensja hrabiego K. Sieversa (3 000 rubli srebrnych rocznie), który nigdy nie był pracownikiem Kolegium, lecz dyrektorem Departamentu Wyznań Obcych MSW. Z kolei emerytury dla duchowieństwa objęły m.in. biskupów będących na zesłaniu lub z niego powracających: abpa Zygmunta Szczęsnego Felińskiego (5 000 rb.), bpa Adama Krasińskiego (4 000 rb.) oraz bpa Pawła Rzewuskiego (1 650 rb.). W roku 1889 fundusz pomocowy wydał więc 165305 rbs. 25 kop., natomiast Skarb Państwa równocześnie, jak co roku, rozdysponował kwotę $578791 \mathrm{rb}$. z konta utworzonego w $1843 \mathrm{r}$.

\footnotetext{
57 Список, passim.

58 Tamże, s. 77.
} 
Bliższej analizy krytycznej, jednak nie pełnej, tych dwu sposobów finansowania potrzeb materialnych Kościoła dokonał dopiero Rząd Tymczasowy w 1917 roku, a zarys tego opracowania będącego podsumowaniem prac mieszanej komisji do spraw Kościoła rzymsko-katolickiego zachował się w archiwach Kolegium ${ }^{59}$. Nadal jednak wskazane są dalsze prace archiwalne nad dziejami tych operacji finansowych, które sygnalizuje tylko powyższy przyczynek. Wspomniany raport sygnowany 19 października 1917 roku przez Antona W. Kartaszewa, nazwany projektem ustawy, podkreśla nadużycia władz carskich, ciągle pozbawiających środowiska katolickie nawet tego, co przyznał im nieżyczliwy Mikołaj I. Autorzy opracowania podkreślają, że nacjonalizacja dóbr kościelnych dokonana na tzw. ziemiach zabranych miała być corocznie rekompensowana sumą $578791 \mathrm{rb}$. i stale rosnącym funduszem pomocowym. Tymczasem, po utworzeniu diecezji tyraspolskiej także jej wydatki (33 237 rbs. 75 kop.) oraz przyznane wcześniej środki dla parafii w Mitawie, Holdingu i Libawie (912 rb. 12 kop.) obciążyły wymienioną kwotę kapitału pomocowego. Podobnie jeszcze przed 1842 r. niektóre parafie były finansowane przez Skarb Państwa, na sumę 20885 rbs. 21 kop. Tymi należnościami od 1866 roku obciążono fundusz pomocowy duchowieństwa. Po nacjonalizacji majątków kościelnych niektórym parafiom winno się przyznać przydomowe nadziały ziemi, której nie otrzymały. Z tego tytułu z kasy państwowej należało się im wynagrodzenie. Szukano także sposobu sfinansowania parafii katolickich obrządku ormiańskiego. I te potrzeby zostały pokryte $\mathrm{z}$ funduszu pomocowego (16 779 rb. 61 kop.). Podobnie opłacono duszpasterzy parafii łacińskiej w Tbilisi (1 $100 \mathrm{rb}$.). Pierwotnie określone koszta utrzymania personelu Kolegium (w 1801 r.) stopniowo rosły. Już w 1867 r. przeniesiono je na barki funduszu pomocowego. Po 100 latach rocznie wyniosły $23000 \mathrm{rb}$.

Autorzy wstępnego projektu ustawy określającej tymczasowe, na czas wojenny, obowiązki państwa wobec Kościoła, uwzględniając powyższe ustalenia, zaproponowali, by wszystkie kwoty niesłusznie obciążające kapitał pomocowy Kolegium katolickiego, zostały wpisane do obowiązków Kasy Państwowej, w której umieszczono znacjonalizowane dobra kościelne. W pierwszej kolejności to nie kapitał pomocowy miał finansować Departament Wyznań Obcych MSW lecz państwo (15 002 rbs.). Po przyjęciu projektowanej ustawy stały budżet przeznaczony na utrzymanie Kościoła wzrósłby z 578791 rb. do 674676 rb., niezależnie od istniejącego nadal funduszu czyli kapitału pomocowego. Rząd Tymczasowy Aleksandra Kiereńskiego podjął już w sierpniu 1917 r. decyzję o rozwiązaniu Kolegium Duchownego, a obydwa konta obsługujące działalność Kościoła przekazać w ręce powstającej Konferencji Episkopatu ${ }^{60}$. Uchwalono również, by skasować podziały na etaty i klasy dla klasztorów i parafii, a sumy na utrzymanie duchowieństwa przekazywać corocznie episkopatowi, które według własnego uznania miało dotować instytucje kościelne w imperium. Kapitały kościelne zaś, zarówno pomocowy jak i remontowy, oddać stopniowo do bezpośredniej dyspozycji Kościoła katolickiego - „Suma ta ogółem wynosić miała około 800 tys. rubli rocznie" $"$.

${ }^{59}$ РГИА, ф. 822, оп. 11, д. 592.

${ }^{60}$ Archivio Segreto Vaticano (dalej: ASV), Russia-Polonia, Periodo 1872-1921, fasc. 508, k. 9-12.

${ }^{61}$ Szelążek, Podstawy dotacji duchowieństwa katolickiego w Polsce, s. 116. 
Na zakończenie autorzy cytowanego dokumentu, pisanego w czasie I wojny światowej, przypominają, że Kolegium posiadało:

\begin{tabular}{|l|l|r|}
\hline 1. & kapitał pomocowy w wysokości & $4948673 \mathrm{rb}$. \\
\hline 2. & odsetki od tej kwoty wynoszą & $202349 \mathrm{rb}$. \\
\hline 3. & remontowy kapitał utworzony w 1846 r. & $353087 \mathrm{rb}$. \\
\hline 4. & odsetki (od pozycji 3) przeznaczane na remonty & 13720 \\
\hline 5. & $\begin{array}{l}\text { kapitał składkowy zachowany po sfinansowaniu parafii } \\
\text { w gub. samarskiej i saratowskiej }\end{array}$ & $38615 \mathrm{rb} .24 \mathrm{kop}$. \\
\hline 6. & odsetki od tego kapitału (nr 5) & $1497 \mathrm{rb} .35 \mathrm{kop}$. \\
\hline 7. & $\begin{array}{l}\text { kapitał funduszowy wieczysty (na zamówione Msze św. } \\
\text { i nabożeństwa) }\end{array}$ & $1522762 \mathrm{rb}$. \\
\hline 8. & odsetki od tego kapitału funduszowego & $60107 \mathrm{rb}$. \\
\hline 9. & adresowany kapitał funduszowy & $202125 \mathrm{rb}$. \\
\hline 10. & odsetki od pozycji 9 & $7994 \mathrm{rb}$. \\
\hline
\end{tabular}

W powyższym zestawieniu występująca w pozycji 9 kategoria - adresowany kapitał funduszowy - najczęściej określany jako духовное завещание - dotyсzył sum ofiarowanych przez wiernych na rzecz poszczególnych kościołów. W najstarszych archiwaliach Kolegium pojawia się rzadko (w 1804 r. tylko dwukrotnie) i dotyczy wyłącznie regulacji prawnych takich zapisów testamentalnych ${ }^{62}$. W miarę upływu czasu przybywa tego rodzaju archiwaliów. Po ukazie tolerancyjnym z 1905 r. jest to zjawisko niemal żywiołowe ${ }^{63}$. Do tej pory nie podjęto prac nad dokładniejszym określeniem ewolucji prawa normującego darowizny na rzecz kościołów ani także faktografii zjawiska w przekroju chronologicznym.

Zamykając swe rozważania, jakby przeczuwając groźbę bolszewickiej rewolucji - jest już 19 październik 1917 - minister wyznań Kartaszew, sam będąc prawosławnym, oświadcza że Kościół katolicki jest ponadto właścicielem nieruchomości, jak wiemy nabytych za własne pieniądze:

a) domu przy ul. Fontanka 118, wartego.........................................466 000 rb.

b) domu przy ul. Pierwszej Roty Pułku Izmaiłowskiego 11, wartego 442400 rb.

c) placów pod obu nieruchomościami i sadu (tzw. польский садик)

wartych $.732000 \mathrm{rb}$.

W sumie nieruchomości te minister wycenił na $1640000 \mathrm{rb}$.

Gromadząc archiwalia do cytowanego sprawozdania autorzy nie uwzględnili m.in. ile wart był w 1917 r. budynek Akademii Duchownej na Wasilewskim Ostrowie, (obecnie - w 2014 r. - używany przez Uniwersytet im. Hercena i Uni-

${ }^{62}$ РГИА, ф. 822, оп. 1, д. 1857, 1920.

${ }^{63}$ РГИА, ф. 822, оп. 8: Wybrane przykładowo kościoły jako adresaci zaofiarowanych kwot w 1908 r.: д. 25 (Tomsk, Zabłudów), 27 (kościół św. Barbary w Witebsku), 34 (Mikołajów), 36 (Kaługa), 41 (Orzeł), 46 (Gatczyna), 47 (Woroneż), 65 (Tobolsk), 66 (Rostow nad Donem), Ryga (kościół św. Franciszka); w 1909 r.: д. 6 (Wiatka), 30 (Kijów, św. Mikołaja), 36, 48 (Odessa), 60 (Orsza); w 1910 r.: д. 28 (Tomsk), 29 (Połtawa), 35 (Smoleńsk), 55 (Kaińsk), 60 (Penza), 77 (Twer), 78 (Tbilisi i Gori). 
wersytet Żydowski) - na który w 1842 r. z kapitału pomocowego wydano około 250000 rb. Projektu Rządu Tymczasowego jednak nie zrealizowano, a wymienione nieruchomości wkrótce przeszły w ręce bolszewików. Tylko niektóre z nich zostały odzyskane po pierestrojce, ale na szczęście ocalały dokumenty, które mogą jeszcze przesądzić o ich dalszej historii.

Słowa kluczowe: Kolegium Rzymsko-katolickie, Departament Wyznań Obcych MSW, fundusz pomocowy, seminaria duchowne, Akademia Duchowna, cezaropapizm, słowianofilstwo, kasata klasztorów, nacjonalizacja beneficjów kościelnych, Rząd Tymczasowy

\section{METHODS OF FINANCING THE CATHOLIC CHURCH IN RUSSIA IN THE NINETEENTH CENTURY. AN ARCHIVAL SUPPLEMENT}

\section{Summary}

The religious policy of the Russian State was inspired by two ideological trends, which were rooted in the tradition of Peter I and Catherine II - Caesaropapism and Slavophilism. Russian rulers sought to subjugate the religious denominations, and also to build a Pan-Slavic empire with the Russian language. With regard to the Catholic Church, those demands proved to be extremely valid as $60 \%$ of the lands of the Polish Republic became part of Russia after the partitions. The tsarist authorities tried to separate Catholics from the Holy See and impose gradually the Russian language and culture on them. Secular authorities wanted to gain control over church institutions - dioceses, seminaries, parishes, monasteries. To achieve that aim, the authorities established the Roman-Catholic College (1801), and subordinated it directly to the Ministry of the Interior. Both organizations exercised full control over ecclesiastical institutions. Lay prosecutors in both of those offices played a decisive role.

At the command of the tsarist regime all the monastic, diocesan and parish properties were gradually taken over, in return certain salaries (1832.1843) were granted to them. On the other hand, at the initiative of Metropolitan Bishop Siestrzeńcewicz S. (1820) so-called assistance fund was created, the aim of which was to finance the special expenses - poor parishes, seminars, Theological Academy, sick and retired priests, deported bishops. Having the assistance fund at their disposal, both the Ministry of the Interior and the College misappropriated funds, often financing even anti-Church actions or well-known enemies of Polish society (K.E. Sievers). A. Kerensky's government prepared a draft reform in this field. However, it was not implemented as it was torpedoed by the revolution of 1917.

Keywords: the Roman-Catholic College, Department of Foreign Confessions of the Ministry of the Interior, assistance fund, theological seminaries, Theological Academy, Caesaropapism, Slavophilism, the dissolution of the monasteries, the nationalization of the church benefices, the Provisional Government 